\title{
Comparison of Ionic Currents Expressed in Immature and Mature Muscle Cells of an Ascidian Larva
}

\author{
Anna K. Davis, Adrienne A. Greaves, Julia E. Dallman, and William J. Moody \\ Department of Zoology, University of Washington, Seattle, WA 98195
}

\begin{abstract}
We have compared the voltage-gated ion channels present in larval ascidian muscle at two developmental stages: muscle precursor cells just after the terminal cell division and mature contractile muscle, 7-11 hr later. All precursor cells express a high-threshold transient $\mathrm{Ca}$ current and a slowly activating delayed $K$ current, and about half the cells express a low-threshold transient Ca current. An inwardly rectifying $K$ current, which had been present from fertilization until just before the terminal cell division, is absent. Mature muscle retains two of the tailbud currents: the low-threshold transient $\mathrm{Ca}$ current and the slow delayed $\mathrm{K}$ current, although at larger densities, and also expresses a high-threshold $\mathrm{Ca}$ current that is similar in most respects to the precursor cell current but that lacks inactivation. In addition, mature muscle expresses two rapidly activating outward $K$ currents, one voltage and one Ca dependent, that generate a composite outward $\mathrm{K}$ current that is eight times larger and activates eight times faster than the tailbud $\mathrm{K}$ current. Mature muscle also reexpresses the inward rectifier. We propose that the transient absence of the inward rectifier and the slow activation of the delayed $K$ current early in development create a window of developmental time when spontaneous electrical activity is likely.
\end{abstract}

[Key words: ion channel, muscle, ascidian larva, Ca channel, $K$ channel, delayed rectifier, development]

In many cells, expression of voltage-gated ion channels is tightly regulated during differentiation. This regulation is manifest in a given cell as a stereotypical sequence in which functional ion channels are expressed. For example, in amphibian neurons, delayed $\mathrm{K}$ currents mature late in development relative to calcium and sodium currents (Barish, 1986; O'Dowd et al., 1988; reviewed in Spitzer, 1991), whereas in amphibian muscle K currents appear in development before either $\mathrm{Ca}$ or $\mathrm{Na}$ currents (Ribera and Spitzer, 1991; Spruce and Moody, 1992). In many cells, the low-threshold transient $\mathrm{Ca}$ current is much more prominent at early stages of development (McCobb et al., 1989; Beam and Knudson, 1988; Gonoi and Hasegawa, 1988; but see Cognard et al., 1993). In amphibian neurons, the late maturation of the delated $\mathrm{K}$ currents appears to regulate spontaneous activity which, in turn, drives a portion of the program of later differ-

Received May 31, 1994; revised Jan. 31, 1995; accepted Feb. 3, 1995.

This work was supported by NIH Grant HD17486 to W.J.M., by an NSF Graduate Fellowship to A.G., and by NIH Training Grant GM07270 to J.E.D. We thank Paul Linsdell and Julie Coombs for critical reading of the manuscript. Correspondence should be addressed to Anna K. Davis at the above address. Copyright $\odot 1995$ Society for Neuroscience 0270-6474/95/154875-10\$05.00/0 entiation (Holliday and Spitzer, 1990; Desarmenien and Spitzer, 1991; Jones and Ribera, 1994). In most cells, however, the significance of the exact developmental sequence in which voltagegated channels are expressed remains poorly understood.

We have studied modulation of ion channel expression during development in the larval muscle of the ascidian Boltenia villosa, a marine invertebrate of the phylum Chordata. Boltenia muscle develops rapidly and contains an orange pigment that is present in oocytes and segregates into the muscle lineage by the eight-cell stage embryo (see Simoncini et al., 1988, for photographs). This pigmentation allows muscle precursor cells to be identified at all stages of development, eliminating a common problem that the program of electrical differentiation begins before cells can be uniquely identified.

Previously, we characterized ion channel development in muscle-lineage blastomeres from fertilization to just after neurulation (Block and Moody, 1987; Simoncini et al., 1988). During early development, a process of sequential channel elimination yields a gastrula in which the muscle precursor cells express only an inwardly rectifying $\mathrm{K}$ current. After neurulation, the precursor cclls lose the inward rectificr and begin to express inward $\mathrm{Ca}$ and outward $\mathrm{K}$ currents.

Here, we continue these studies by comparing the $\mathrm{Ca}$ and $\mathrm{K}$ currents in tailbud stage muscle precursor cells, which have just completed their terminal division ("tailbud precursor cells"), to those in mature contractile larval muscle. Tailbud precursor cells express low- and high-threshold transient $\mathrm{Ca}$ currents and a slowly activating delayed $\mathrm{K}$ current. Mature muscle cells retain two of these currents, although at higher density (the low-threshold transient Ca current and the slow delayed K current), express three new currents (a low-threshold voltage-dependent outward $\mathrm{K}$ current, a Ca-dependent outward $\mathrm{K}$ current, and the inward rectifier), and appear to retain one current in modified form (the high-threshold $\mathrm{Ca}$ current, which loses its inactivation). As a result of these changes in ion channel expression, composite inward and outward currents in mature muscle are larger, faster, and activate at more negative potentials than in precursor cells. The slow activation, high threshold, and relatively small amplitude of the delayed $\mathbf{K}$ current in the precursor cells results in an action potential of similar amplitude, but threefold longer duration than that recorded in mature muscle. The absence of the inward rectifier would be expected to destabilize the resting potential of the precursor cells and favor the spontaneous occurrence of such long-duration action potentials. In current-clamp recordings, more than half the precursor cells, but no mature muscle cells, showed spontaneous action potentials.

\section{Materials and Methods}

Animals. Boltenia villosa were collected from the Puget Sound and maintained in seawater at $10-12^{\circ} \mathrm{C}$ with constant light to discourage 
spawning. Procedures for harvesting gametes, fertilizing eggs, and rearing embryos were described previously (Block and Moody, 1987). We define tailbud as the larval stage just after neural tube closure, 6-10 hr after the start of gastrulation $\left(12^{\circ} \mathrm{C}\right)$, a stage at which the tail has extended sufficiently to curl inside the chorion (about $2 \mathrm{hr}$ after early tailbud formation and $19.5-24 \mathrm{hr}$ after fertilization, $12^{\circ} \mathrm{C}$ ). The tadpole stage is defined as the stage just after the larvae hatch from within the chorion $\left(31 \pm 4 \mathrm{hr}\right.$ after fertilization, $\left.12^{\circ} \mathrm{C}\right)$.

Solutions. Bath solutions (extracellular)-Artificial seawater (ASW) contained (mM) $400 \mathrm{NaCl}, 10 \mathrm{KCl}, 10 \mathrm{CaCl}_{2}, 50 \mathrm{MgCl}_{2}, 10$ HEPES, $\mathrm{pH} 8$ with $\mathrm{NaOH}$. Divalent-free ASW (DF ASW) contained (mM) 460 $\mathrm{NaCl}, 10 \mathrm{KCl}, 10 \mathrm{HEPES}, 5 \mathrm{EGTA}, \mathrm{pH} 8$ with $\mathrm{NaOH}$. The composition of $0 \mathrm{Ca} \mathrm{ASW}$ is the same as ASW except that $10 \mathrm{~mm} \mathrm{CaCl}_{2}$ was replaced by $10 \mathrm{mM} \mathrm{MgCl}$ to generate a final concentration of $60 \mathrm{MgCl}_{2}$. The composition of $10 \mathrm{Ba} / 0 \mathrm{Ca} \mathrm{ASW}$ is the same as for $0 \mathrm{Ca} \mathrm{ASW}$ except for the substitution of $10 \mathrm{mM} \mathrm{BaCl}_{2}$ for $10 \mathrm{mM} \mathrm{MgCl}_{2} .10 \mathrm{Ba}$ ASW/10 Ca ASW contained the same constituents as ASW except 10 $\mathrm{mM} \mathrm{BaCl}{ }_{2}$ replaced $10 \mathrm{mM} \mathrm{MgCl}_{2}$. Pronase ASW contained $1 \mathrm{mg} / \mathrm{ml}$ Pronase E (TYPE XIV, Sigma) in ASW.

Pipette (internal) solutions-Normal internal solution contained (mM) $10 \mathrm{NaCl}, 200 \mathrm{KCl}, 1 \mathrm{MgCl}_{2}, 1$ EGTA, 20 HEPES, 2 MgATP, 0.1 cAMP, $400 d$-sorbitol, pH 7.3 with $16 \mathrm{mM} \mathrm{KOH}$. This solution was preserved from an initial series of experiments using non-nystatin whole-cell clamp even though nystatin probably eliminated the necessity of using MgATP and cAMP. To block outward potassium currents, $\mathrm{KCl}$ was replaced with equimolar $\mathrm{CsCl}$ and the solution $\mathrm{pH}$ adjusted with $\mathrm{CsOH}$. Sorbitol was added to all intracellular solutions to balance osmolarity. Nystatin (Sigma) containing internal solution for perforated patch recordings was made by diluting a stock solution of nystatin $(30 \mathrm{mg} / \mathrm{ml}$ in DMSO, stored at $-20^{\circ} \mathrm{C}$ ) into internal solution (final concentration of $300 \mu \mathrm{g} / \mathrm{ml}$ ) just prior to experimentation. The pipette tip was filled with non-nystatin internal solution and then backfilled with nystatincontaining internal solution.

Preparation of cells for recording. To isolate tailbud stage muscle precursor cells, the chorion was removed manually with tungsten needles in DF ASW. The embryos were transferred to Pronase ASW for $10 \mathrm{~min}$, then returned to DF ASW and gently triturated to isolate single cells, which were transferred to normal ASW for recording. Tadpoles hatch from within the chorion $27-35 \mathrm{hr}\left(12^{\circ} \mathrm{C}\right)$ after fertilization. These motile tadpoles were transferred from ASW to Pronase ASW for 30 min to $1 \mathrm{hr}\left(12^{\circ} \mathrm{C}\right)$. After pronase treatment, tadpoles were transferred to DF ASW for 30-45 min and then were gently triturated to isolate single cells. Following isolation, cells were transferred gradually from DF ASW to normal ASW for recording. Cells isolated using this procedure were viable and mature cells twitched in response to depolarization.

Electrophysiological methods. The perforated patch configuration of the whole-cell technique (Horn and Marty, 1988) was used for all voltage- and current-clamp recordings. This configuration minimized washout of calcium and calcium-dependent currents, and resulted in more stable series resistance than conventional whole-cell recordings, probably because it eliminated clogging of the pipette tip by yolk granules. Pipettes for whole-cell clamp were pulled from $50 \mu \mathrm{l}$ hematocrit glass (VWR Scientific) to resistances of $1-4 \mathrm{M} \Omega$ (measured in ASW) using a two-stage puller. Currents were measured using a DAGAN 8900 amplifier, filtered at $0.5 \mathrm{kHz}$ (eight-pole Bessel filter), and acquired at 2 $\mathrm{kHz}$ using pCLAMP software. Series resistance was compensated electronically and was never greater than $10 \mathrm{M} \Omega$ Leakage currents were very small and were not subtracted from recordings. Current-clamp recordings were only accepted for analysis if the input resistance measured at $-60 \mathrm{mV}$ was greater than $4 \mathrm{G} \Omega$ Current density was calculated by dividing total current amplitude by cell capacitance (Simoncini and Moody, 1991). For Ca currents and the inward rectifier, densities were calculated at voltages where peak currents occurred (usually $+20 \mathrm{mV}$ and $-140 \mathrm{mV}$, respectively). [The inward rectifier amplitude declines at more negative voltages due to block by external cations (see Fig. $6 B$; Ohmori, 1978).] Outward $\mathrm{K}$ current densities were calculated at +60 $\mathrm{mV}$, where conductances were maximal. All data is reported as mean $\perp$ standard deviation except where noted. All recordings were made at $10-12^{\circ} \mathrm{C}$.

\section{Results}

Summary of tailbud and tadpole currents

Wholc-cell voltage-clamp recordings from tailbud precursor cells showed a very different pattern of voltage-activated cur-

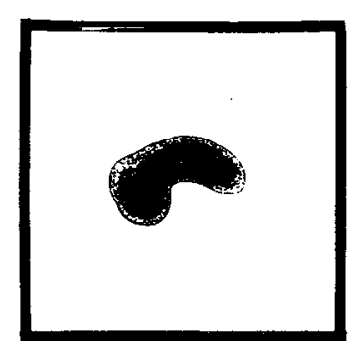

Tailbud

A.

B.
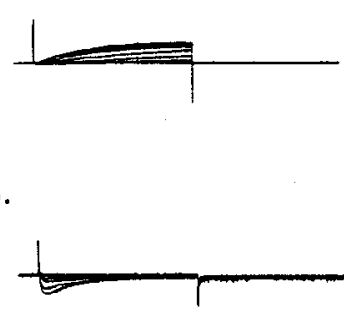

C.

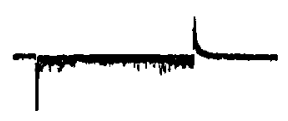

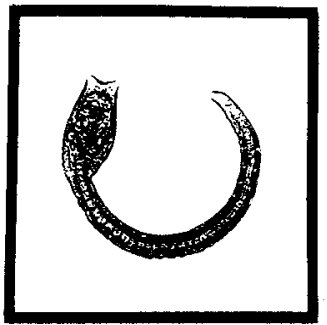

Tadpole

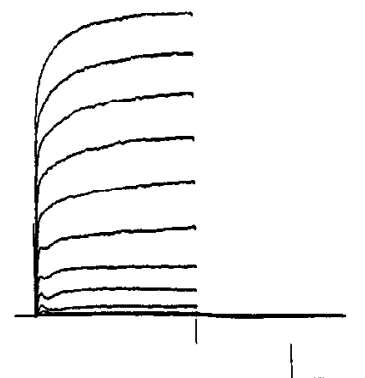

.
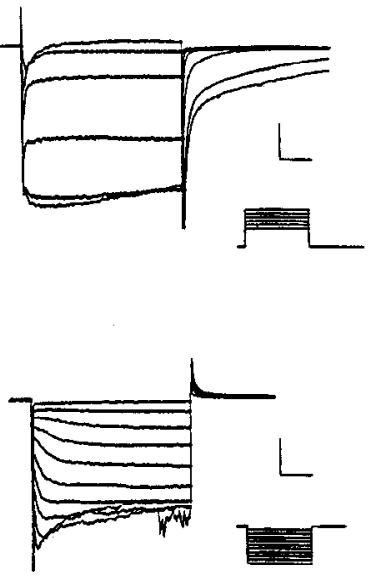

Figure 1. Composite outward and inward currents in tailbud muscle precursor cells (left) and mature tadpole muscle (right). A, Outward $\mathrm{K}$ currents activated by $10 \mathrm{mV}$ steps from $-50 \mathrm{mV}$ to $+60 \mathrm{mV}$ ( $V_{\text {hold }}$

$-60 \mathrm{mV}$ ) in a muscle precursor cell from a tailbud-stage embryo (left) and in a mature tadpole muscle cell (right). Bath, ASW; pipette, 200 $\mathrm{mm} \mathrm{K}$ internal solution. $B$, Inward currents activated by $10 \mathrm{mV}$ steps from $-30 \mathrm{mV}$ to $+20 \mathrm{mV}\left(V_{\text {hold }}=-80 \mathrm{mV}\right)$ in tailbud and tadpole cells. Bath, ASW; pipette, $200 \mathrm{~mm}$ Cs internal solution. $C$, Inwardly rectifying $\mathrm{K}$ currents activated by $-10 \mathrm{mV}$ steps from $-70 \mathrm{mV}$ to -140 $\mathrm{mV}\left(V_{\text {hold }}=-60 \mathrm{mV}\right)$. Mature muscle expressed an inwardly rectifying $\mathrm{K}$ current (right) but no currents were seen in the tailbud muscle precursor (left). Bath, ASW; pipette, $200 \mathrm{~mm} \mathrm{~K}$ internal solution. Calibration: $A, 900 \mathrm{pA} ; B, 90 \mathrm{pA} ; C, 40 \mathrm{pA} ; 100 \mathrm{msec}$ time for all.

rents than those from mature muscle cells (Fig. 1). With $\mathrm{K}$ in the pipette solution, composite records of voltage-activated currents at both stages were dominated by outward currents (Fig. $1 A$ ). Tailbud precursor cells responded to depolarizing voltage pulses with a relatively slowly activating, sustained outward current (Fig. 1A, left). In contrast, mature tadpole muscle showed a much larger and more rapidly activating outward current with a complex waveform consisting of transient and sustained components (Fig. $1 A$, right). With $\mathrm{Cs}$ in the pipette solution to block outward $\mathrm{K}$ currents, the tailbud cells showed a transient inward current in response to depolarization (Fig. $1 B$, left). In about $50 \%$ of the tailbud cells a second, very small amplitude lower 
A.
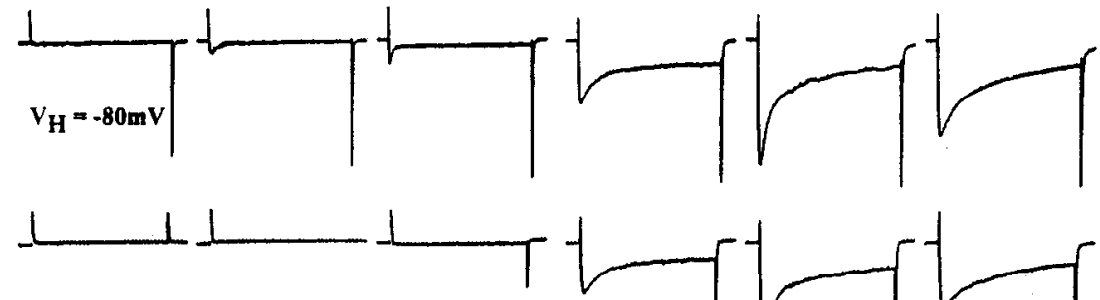

$V_{H}=-30 \mathrm{mV}$

B.

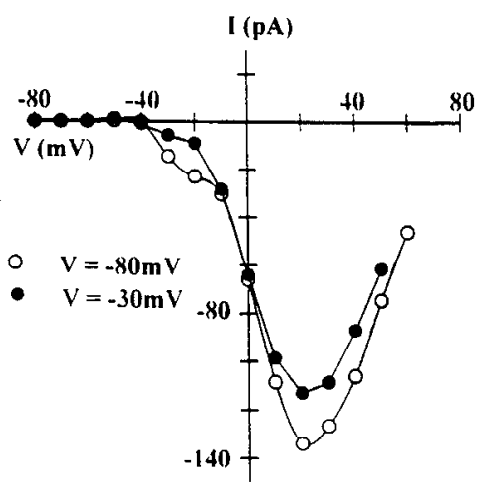

D.
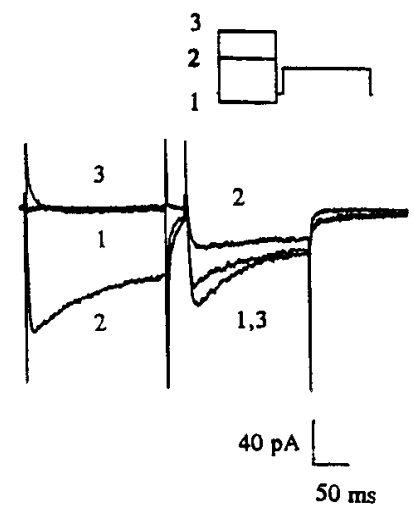

C.

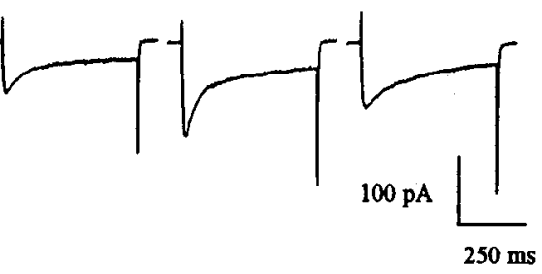

ASW

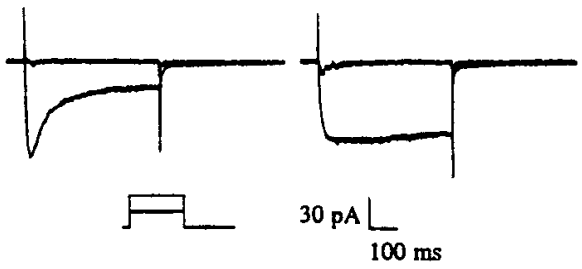

E.

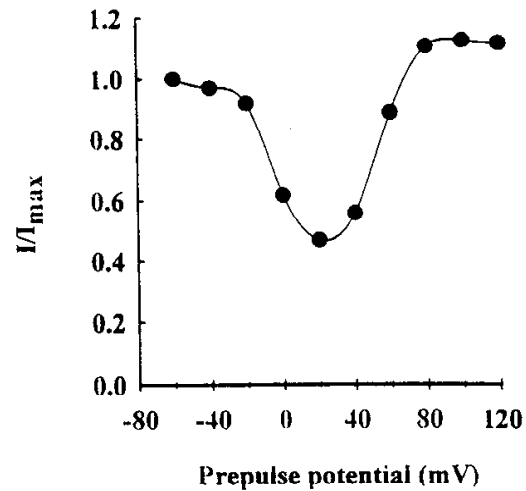

Figure 2. Two Ca currents in immature tailbud-stage muscle precursor cells. $A, \mathrm{Ca}$ currents recorded at voltages of (left to right) $-40 \mathrm{mV},-30$ $\mathrm{mV},-20 \mathrm{mV}, 0 \mathrm{mV},+20 \mathrm{mV}$, and +40 $\mathrm{mV}$ from a holding potential of either $-80 \mathrm{mV}$ (top records) or $-30 \mathrm{mV}$ (bottom records). A small transient low-threshold $(-30 \mathrm{mV}) \mathrm{Ca}$ current was detected in about $50 \%$ of the tailbud-stage cells; it was usually smaller than in the cell shown here. A larger, high-threshold $\mathrm{Ca}$ current that had both transient and noninactivating components was seen in all cells. The lowthreshold current was completely inactivated at $V_{\text {hold }}=-30 \mathrm{mV}$. In the cell shown, the high-threshold component was reduced by about $20 \%$ at $V_{\text {bld }}=$ $-30 \mathrm{mV}$; in other cells it was reduced as much as $40 \%$. Bath, ASW; pipette, $200 \mathrm{~mm}$ Cs internal solution. $B$, Plot of peak current versus voltage for the records shown in $A$. C, Substitution of $\mathrm{Ba}$ for $\mathrm{Ca}$ as the permeant ion in the external solution eliminated inactivation of the high-threshold current but did not affect the low-threshold current $\left(V_{\text {hold }}=-80 \mathrm{mV}\right.$, test pulses to -20 $\mathrm{mV}$ and $+20 \mathrm{mV}$ ). $D$, Two-pulse experiment to demonstrate $\mathrm{Ca}$-dependent inactivation of the high-threshold current. Prepulses to potentials that generated maximal $\mathrm{Ca}$ influx (trace 2 to $+20 \mathrm{mV}$ ) reduced the amplitude of $\mathrm{Ca}$ current stimulated by the test pulse to $+10 \mathrm{mV}$. Prepulses that generated little $\mathrm{Ca}$ influx (trace 1 to $-80 \mathrm{mV}$, trace 3 to $+80 \mathrm{mV}$ ) had little effect on the amplitude of the Ca current stimulated by the test pulse to $+10 \mathrm{mV}$ ( $V_{\text {hold }}=-60$ $\mathrm{mV}$ ). $E$, Data in $D$ plotted as normalized peak Ca current during the test pulse vs prepulse voltage. The inactivation versus voltage relation is $\mathrm{U}$ shaped, with the minimum centered at the potential where the calcium current was maximal $(20 \mathrm{mV})$, indicating a dependence of inactivation on Ca entry. threshold inward current was stimulated by depolarization (not shown). In mature muscle, depolarization generated a much larger inward current with at least two components, onc transient and the other sustained (Fig. 1B, right). Large slowly inactivating inward tail currents were also seen in these mature cells with depolarization to potentials greater than $-10 \mathrm{mV}$. As discussed below, these appeared to reflect $\mathrm{Na}$ and $\mathrm{K}$ influx through $\mathrm{Ca}-$ dependent $\mathrm{K}$ channels. Hyperpolarizing voltage pulses did not stimulate any time- or voltage-dependent currents in tailbud cells (Fig. $1 C$, left). In contrast, mature muscle cells responded to hyperpolarization with an inwardly rectifying current (Fig. $1 C$, right). The mean cell membrane capacitance changed slightly, but significantly with development (tailbud: $16.9 \pm 2.1 \mathrm{pF}, n=$ 21 ; tadpole: $19.7 \pm 2.8 \mathrm{pF}, n=25 ; p<0.001$, two-tailed $t$ test). In the following sections, we separate and characterize the voltage-gated currents expressed at these two developmental stages.

\section{Calcium currents in tailbud precursor cells}

Tailbud precursor cells showed two distinct inward currents activated by depolarization (Fig. 2): a very small amplitude, lowthreshold, fast activating current detected in about $50 \%$ of the cells, and a more slowly activating, high-threshold current with both transient and sustained components, seen in all cells. Both currents were eliminated by removal of external $\mathrm{Ca}$ and unaffected by $\mathrm{Na}$ removal.

Figure $2 A$ shows Ca currents stimulated by depolarizing voltage steps (to $-40 \mathrm{mV},-30 \mathrm{mV},-20 \mathrm{mV}, 0 \mathrm{mV},+20 \mathrm{mV}$, and $+40 \mathrm{mV}$ ) from holding potentials of $-80 \mathrm{mV}$ (top records) or $-30 \mathrm{mV}$ (bottom records) in a tailbud precursor cell. A plot of the current-voltage relations for the cell in $A$ is shown in Figure $2 B$. From $V_{\text {hold }}=-80 \mathrm{mV}$, a very small $(0.1-0.3 \mathrm{pA} / \mathrm{pF}$ at -20 $\mathrm{mV}$ ), fast-activating, transient Ca current was stimulated by voltage steps to potentials more positive than $-30 \mathrm{mV}$. This low- 
Figure 3, Two Ca currents in mature tadpole muscle cells. $A$, Ca currents activated by $20 \mathrm{mV}$ steps from $-40 \mathrm{mV}$ to $+60 \mathrm{mV}$ with $V_{\text {hold }}=-80 \mathrm{mV}$ (top records) or $V_{\text {hold }}-30 \mathrm{mV}$ (bottom records). Most tadpole-stage cells responded to depolarization with both a low-threshold (activated at $-30 \mathrm{mV}$ ), transient current and a high-threshold (activated at $-10 \mathrm{mV}$ ), sustained current. The transient current was inactivated and the high-threshold current was relatively unaffected by shifting holding potential to $-30 \mathrm{mV}$. Bath ASW; pipette, $200 \mathrm{~mm}$ Cs internal solution. $B$, Peak current versus voltage plot for records shown in A filled symbols) and a current versus voltage relation for the low-threshold transient Ca current (open symbols) obtained by subtraction of the $-30 \mathrm{mV}$ (filled triangles) $\mathrm{I}-\mathrm{V}$ from that taken from -80 $\mathrm{mV}$ (filled circles). C, Substitution of $\mathrm{Ba}$ for $\mathrm{Ca}$ as the permeant ion in the external solution did not affect the waveform of either current but did reduce the amplitude and duration of the prominent slow tail currents (see Results) that followed depolarizations to potentials greater than -10 to $0 \mathrm{mV}$ $\left(V_{\text {hold }}=-80 \mathrm{mV}\right.$, test pulses to -20 $\mathrm{mV}$ and $+20 \mathrm{mV})$. The current carried by $\mathrm{Ba}(10 \mathrm{~mm})$ is only slightly smaller than that carried by $\mathrm{Ca}(10 \mathrm{~mm})$ when superimposed on current washout, as is also observed for the precursor cell high-threshold current (see Results).
A.

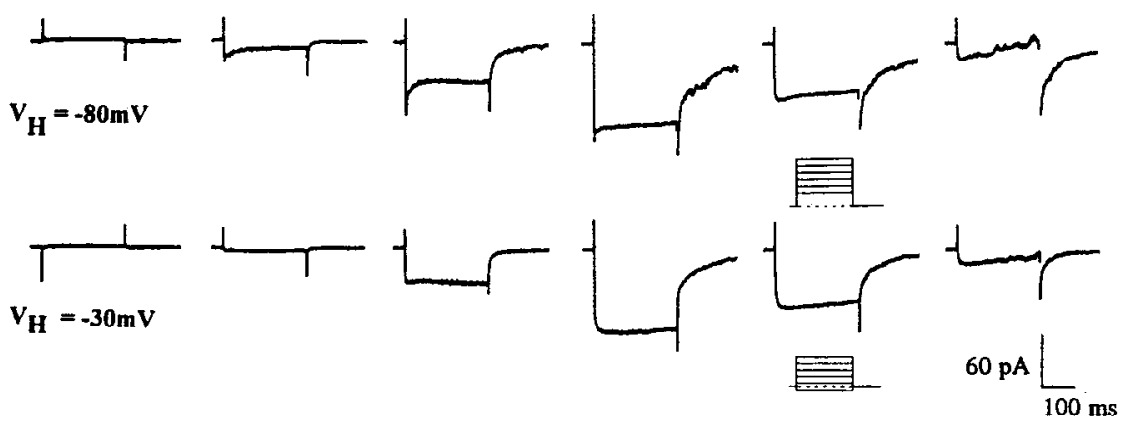

B.

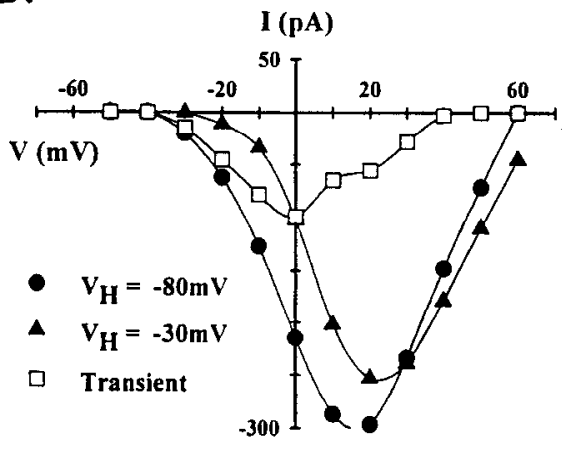

C.

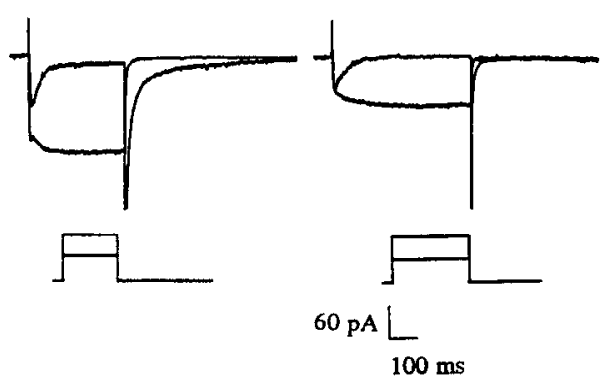

threshold Ca current was completely inactivated by shifting to $V_{\text {hold }}=-30 \mathrm{mV}$. A second Ca current was activated with voltage steps to more positive potentials $\left(-15 \mathrm{mV}\right.$ to $-10 \mathrm{mV}$ with $V_{\text {hold }}$ $=-80 \mathrm{mV}$ ). This high-threshold Ca current also inactivated, had slower activation and inactivation kinetics than the lowthreshold current, and showed a significant sustained component. The time to peak for the high-threshold current was $21.8 \pm 4.4$ msec $(n=16)$ and the time constant for inactivation was $89 \pm$ $22 \mathrm{msec}(n=11)$ at $+20 \mathrm{mV}$, the potential where maximal current was activated. The average peak density of the highthreshold current was $4.7 \pm 2.2 \mathrm{pA} / \mathrm{pF}(n=17)$. There was a $20-40 \%$ reduction in the amplitude of both the transient and sustained components of the high-threshold current when holding potential was shifted to $-30 \mathrm{mV}$, most likely due to the sensitivity of the current to Ca-dependent rather than voltagedependent inactivation, as discussed below.

Two other divalent ions, barium and strontium, can act as charge carriers for the low-threshold and high-threshold inward currents of tailbud muscle. These ions also permeate calcium channels expressed in the fertilized egg and late neurula stage einbryo (Simoncini and Moody, 1991). In previous work, we demonstrated that inactivation of the high-threshold Ca currents expressed at both of these early stages was dependent on $\mathrm{Ca}$ entry. Figure $2 C$ shows that in the tailbud precursor cells, too, inactivation of the high-threshold $\mathrm{Ca}$ current was eliminated when $\mathrm{Ba}$ was substituted for $\mathrm{Ca}$ in the extracellular solution, implying that at this stage also, rapid inactivation during the voltage pulse is dependent on Ca entry. Inactivation of the lowthreshold transient current was unaffected by $\mathrm{Ba}$, implying a voltage-dependent inactivation mechanism, as is typical for low- threshold, or T-type, Ca currents in other cells (Hess, 1990). The high-threshold current carried by $\mathrm{Ba}(10 \mathrm{mM})$ is slightly smaller than that carried by $\mathrm{Ca}(10 \mathrm{~mm}$ ) (Fig. $2 \mathrm{C}$; see also Fig. $3 \mathrm{C}$ for mature muscle). This differs from the situation in $50 \mathrm{mM}$ Ca or $\mathrm{Ba}$ where the current carried by $\mathrm{Ba}$ is larger than that carried by Ca (Simonicini and Moody, 1990). This may be explained by a difference in conductance saturation for $\mathrm{Ca}$ and $\mathrm{Ba}$ (see Cota and Stefani, 1984; Fox et al., 1987). Figure 2, $D$ and $E$, shows that the inactivation versus voltage relation for the high-threshold calcium current determined by brief prepulses is $U$ shaped, another indication of Ca-dependent inactivation. The calcium current stimulated by a test pulse to $+20 \mathrm{mV}$ (Fig. $2 \mathrm{D}$ ) showed maximal inactivation when the prepulse potential generated maximal Ca current $(+20 \mathrm{mV})$ (Fig. $3 D$, trace 2$)$ and almost no inactivation at prepulse potentials where $\mathrm{Ca}$ entry was expected to be minimal $(-80 \mathrm{mV}$, trace 1 , or $+80 \mathrm{mV}$, trace 3$)$. An inactivation versus voltage relation derived from this prepulse experiment is shown in Figure $3 E$.

High concentrations of the dihydropyridine nifedipine (100 $\mu \mathrm{M})$ decreased the high-threshold current by $51 \pm 17 \%(n=$ 9), but had no effect on the low-threshold current.

\section{Ca currents in contractile mature muscle cells}

All mature tadpole muscle cells (7-11 hr after the tailbud stage) showed two inward currents that could be distinguished by their voltage dependence, kinetics of activation and inactivation, and sensitivity to dihydropyridines. Both currents were abolished by removal of calcium from the external solution and unaffected by removal of sodium.

Figure $3 A$ shows currents activated by $20 \mathrm{mV}$ steps from -40 
$\mathrm{mV}$ to $+60 \mathrm{mV}$ (holding potentials of $-80 \mathrm{mV}$ and $-30 \mathrm{mV}$ ) using a pipette solution in which $\mathrm{Cs}$ was substituted for $\mathrm{K}$ to eliminate outward $\mathrm{K}$ currents. The resulting current-voltage relations are plotted in Figure $3 B$. From $V_{\text {hold }}$ of $-80 \mathrm{mV}$, a lowthreshold, transient inward current was activated at potentials positive to $-30 \mathrm{mV}$. The peak of this current occurred at -10 $\mathrm{mV}$ to $0 \mathrm{mV}$. At $-20 \mathrm{mV}$, a potential where the current was easily isolated, the current activated to peak in $9.46 \pm 2.5 \mathrm{msec}$ $(n=19$,) and had an inactivation time constant of about 30 msec. A second inward current was activated at potentials positive to $-10 \mathrm{mV}$ (Fig. $3 A$ ). The peak of this high-threshold current occurred at $+20 \mathrm{mV}$. The low-threshold Ca current could be selectively inactivated by a holding potential of $-30 \mathrm{mV}$ (Fig. 3A,B), isolating the high-threshold component. This highthreshold current was more slowly activating and had a sustained amplitude throughout the duration of the $500 \mathrm{msec}$ pulse. The high-threshold current was little affected by shifting holding potential to $-30 \mathrm{mV}$ or prepulses $(200 \mathrm{msec})$ to potentials as positive as $-10 \mathrm{mV}$. The mean density of the high-threshold current was $23.4 \pm 10 \mathrm{pA} / \mathrm{pF}(n=25)$ compared to $4.7 \pm 2.2 \mathrm{pA} / \mathrm{pF}$ $(n=17)$ for precursor cells. Activation and inactivation of the low-threshold $\mathrm{Ca}$ current occur at somewhat more positive voltages than in many mammalian cells (see, e.g., Narahashi et al., 1987) perhaps due to charge screening by the high concentrations of divalent cations normally present in seawater.

Substitution of $\mathrm{Ba}$ for $\mathrm{Ca}$ in the external solution did not affect the kinetics of either Ca current (Fig. 3C). This is not surprising, because the high-threshold $\mathrm{Ca}$ current in mature muscle does not inaclivate even when $\mathrm{Ca}$ is the charge carrier. The low-threshold transient current of the mature cells thus appears to be voltage inactivated and seems to be identical to the low-threshold current of the tailbud precursor cells, only much larger. Its larger size allowed us to measure more accurately its voltage dependence of inactivation. For the cell shown in Figure $3, A$ and $B$, an inactivation plot was well fit by a Boltzmann relation with $V_{1 / 2}$ $=-45 \mathrm{mV}$ and $k=5.3$.

As in immature cells, nifedipine $(100 \mu \mathrm{M})$ decreased the amplitude of the high-threshold sustained Ca current (by $70 \pm 9 \%$; $n=7$ ), but did not affect the low-threshold current.

In summary, the low-threshold transient current of mature muscle resembles the low-threshold Ca current detected in about $50 \%$ of tailbud precursor cells in voltage dependence, rate of activation, and sensitivity to voltage-dependent inactivation. The low-threshold current is seen in most mature cells and shows at least a fivefold larger density than in the precursor cells. The high-threshold $\mathrm{Ca}$ current of mature muscle shares voltage dependence of activation and sensitivily to dihydropyridines with the immature muscle high-threshold current, but these currents differ in inactivation properties: the mature cell $\mathrm{Ca}$ current has a sustained amplitude throughout a $600 \mathrm{msec}$ voltage step, whereas the tailbud-stage current shows a substantial component of Ca-dependent inactivation. The high-threshold current in mature cells is also about five times larger than the high-threshold current in immature cells, although this might be a slight overestimate if inactivation of the tailbud $\mathrm{Ca}$ current truncates the peak amplitude significantly. Since the two currents share many properties, it is possible that the two represent different isoforms or posttranslationally modified versions of the same channel type. It is also possible that the channels underlying the two $\mathrm{Ca}$ currents are identical, and that the lack of inactivation of the current in mature muscle reflects an increase in internal calcium buffering ability in mature muscle related, for example, to the maturation of the excitation-contraction apparatus.

Another notable feature of the records from mature muscle using $\mathrm{Cs}$ as the major internal cation was the presence of large, long-lasting tail currents following pulses that activated the highthreshold Ca current (Fig. 3A,C). These tails were not seen in the precursor cells. These tail currents were virtually eliminated when $\mathrm{Ba}$ was substituted for $\mathrm{Ca}$ in the external solution (Fig. $3 C$ ) and were much reduced when the preceding voltage pulse was shortened, even though the pulse was still long enough to allow the $\mathrm{Ca}$ current to reach peak amplitude. Furthermore, the current-voltage relation for the tail currents was U-shaped; maximum tail current occurred at $+20 \mathrm{mV}$, where $\mathrm{Ca}$ entry was greatest, and was reduced at potentials where Ca entry was less (i.e., at $\% 40 \mathrm{mV}$ and $0 \mathrm{mV}$ ). These properties and the fact that large Ca-dependent $\mathrm{K}$ currents appear at about the same developmental stage as the tail currents (unpublished observations) suggest that the tail currents arise from $\mathrm{K}$ influx through $\mathrm{Ca}$ dependent $\mathrm{K}$ channels. Removal of external $\mathrm{K}$ reduces the tail current amplitude by approximately $50 \%$; this is what might be expected even for a K-selective channel, given the large excess of $\mathrm{Na}$ in the external solution. We cannot, however, rule out the possibility that the tail currents arise from $\mathrm{Ca}$-dependent nonselective cation or $\mathrm{Cl}$ channels (see, e.g., Hussy, 1991), although we have no independent evidence for such currents in these cells. Since the tail currents are not present when $\mathrm{KCl}$ is used in the internal solution even though internal and external $\mathrm{Cl}$ concentrations are the same as when $\mathrm{CsCl}$ is used internally, we consider it unlikely that the tails arise from current through $\mathrm{Ca}^{-}$ dependent nonselective cation or $\mathrm{Cl}$ channels.

\section{$K$ currents in tailbud precursor cells and in mature muscle}

Outward currents in cells at both tailbud and tadpole stages were blocked when Cs was substituted for $\mathrm{K}$ in the internal solution, indicating that the outward currents are carried by potassium. In addition, tail currents for these outward currents reversed near the predicted reversal potential for potassium $\left(E_{\mathrm{rev}}=-75 \mathrm{mV}\right.$, $10^{\circ} \mathrm{C}$ ) and far from the predicted reversal potentials for other likely charge carriers $(\mathrm{Cl},-23 \mathrm{mV} ; \mathrm{H},-41 \mathrm{mV})$.

The composite outward $\mathrm{K}$ currents in mature muscle are much larger, faster activating, and more complex in waveform than those of the tailbud precursor cells (Figs. 1A, 4A). The mean density for the total outward current measured at $+40 \mathrm{mV}$ in mature muscle was $168 \pm 46 \mathrm{pA} / \mathrm{pF}(n=12)$ as compared to $20 \pm 13 \mathrm{pA} / \mathrm{pF}(n=22)$ in the tailbud precursor cells. The activation time for the composite outward current in mature muscle (calculated as time to $63 \%$ maximum since the outward $\mathrm{K}$ current had a complex waveform in ASW) was $8.4 \pm 1.9$ $\operatorname{msec}(n=16)$ as compared to $67 \pm 16 \mathrm{mscc}(n=9)$ in the muscle precursor cells (calculated as $\tau$ from single exponential fits). Almost all mature muscle cells showed at least three kinetic components to the outward current: a fast transient current, a low-threshold, fast activating, sustained current, and a higher threshold more slowly activating current. Tailbud precursor cells, on the other hand, showed only a higher threshold, slowly activating component, which could be fit by a single exponential in all cells (Figs. 1A, 5A). Below we show that (1) a large and rapidly activating $\mathrm{Ca}$-dependent $\mathrm{K}$ current appears in the mature muscle cells; (2) the voltage-dependent $\mathrm{K}$ current present in the tailbud precursor cells increases in density in the mature muscle cells, but retains its kinetics and voltage dependence; and (3) a 
A.

$$
\text { Tailbud }
$$

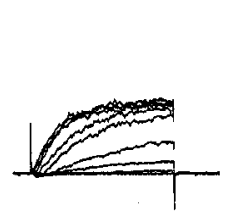

B.

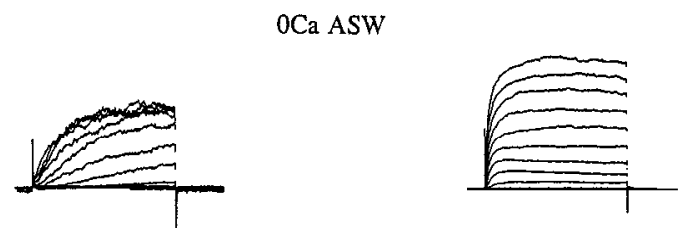

C.

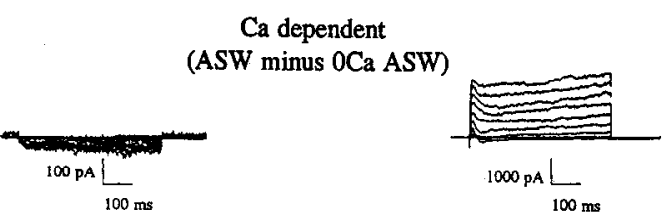

D.
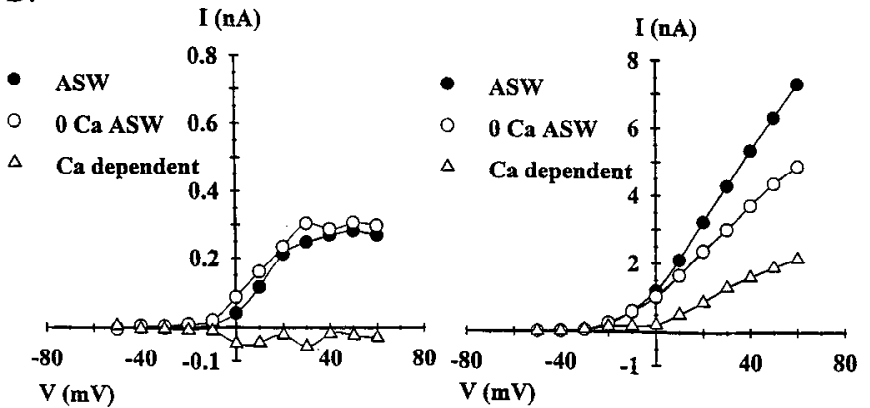

Figure 4. Rapidly activating Ca-dependent $\mathrm{K}$ currents in mature tadpole muscle but not in tailbud muscle precursor cells. A, Composite outward $\mathrm{K}$ currents stimulated by $10 \mathrm{mV}$ steps from $-50 \mathrm{mV}$ to +60 $\mathrm{mV}$ in a tailbud-stage muscle precursor cell (left) and a mature tadpole muscle cell (right) $\left(V_{\text {tulul }}=-60 \mathrm{mV}\right)$. Bath, ASW; pipette, $200 \mathrm{mM} \mathrm{K}$ internal solution. $B$, Removal of $\mathrm{Ca}$ from the bath solution isolates voltage-dependent outward $\mathrm{K}$ currents. The rate of activation and the amplitude of the tadpole stage $\mathrm{K}$ currents (right) stimulated by $10 \mathrm{mV}$ steps from $-50 \mathrm{mV}$ to $+60 \mathrm{mV}\left(V_{\text {hold }}=-60 \mathrm{mV}\right)$ were decreased in $0 \mathrm{Ca}$, whereas the tailbud-stage $\mathrm{K}$ currents (left) were unchanged. Bath, $0 \mathrm{Ca} \mathrm{ASW}$; pipelte, $200 \mathrm{~mm} \mathrm{~K}$ internal solution. $C$, Outward $\mathrm{Ca}$-dependent $\mathrm{K}$ currents in tadpole-stage muscle obtained by subtraction of records in $0 \mathrm{Ca} \mathrm{ASW}$ from those in $\mathrm{ASW}$, showing their rapid activation and both transient and sustained components (right). No Ca-dependent $\mathrm{K}$ currents were detected in immature muscle precursor cells (by subtraction of $0 \mathrm{Ca}$ ASW records from ASW records) (left). $D$, Current versus voltage relations for currents shown in $A-C$ from both developmental stages.

low-threshold voltage-dependent $\mathrm{K}$ current appears in the mature muscle cells.

The contribution of Ca-dependent $\mathrm{K}$ currents to the total outward current was assessed by exposing cells at each developmental stage to an external solution in which all $\mathrm{Ca}$ was replaced by $\mathrm{Mg}(0 \mathrm{Ca} \mathrm{ASW})$. Figurc $4 B$ shows that this had little, if any, effect on the outward currents in the tailbud precursor cells, leading us to conclude that the outward currents in these cells are carried through purely voltage-dependent $\mathrm{K}$ channels. The outward current activated by depolarization appears to be of a single type, because in all of these cells, $\mathrm{K}$ current activation was well fit by a single exponential. In contrast, in mature mus-
A.

Tailbud

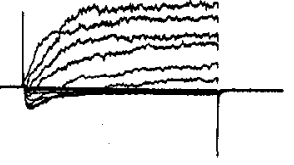

Control

Tadpole

B.

$10 \mathrm{Ba} / 0 \mathrm{Ca} \mathrm{ASW}$
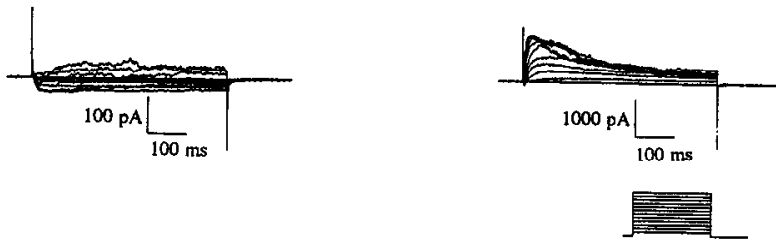

C.

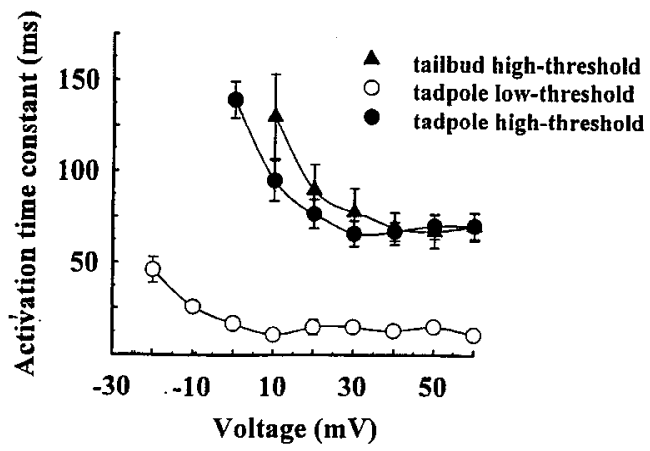

Figure 5. Similarity of voltage-dependence, kinetics, and Ba block of the single outward $\mathrm{K}$ current in tailbud precursor cells and the highthreshold voltage-dependent $\mathrm{K}$ current in mature muscle. A, Voltagedependent outward $\mathrm{K}$ currents in tailbud (left; ASW external solution) and tadpole stage (right; 0 Ca ASW external solution) muscle. Cells were depolarized in $10 \mathrm{mV}$ steps from $-50 \mathrm{mV}$ to $+60 \mathrm{mV}$ ( $V_{\text {hold }}=$ $-60 \mathrm{mV}$ ). Pipettes contained $200 \mathrm{~mm} \mathrm{~K}$ internal solution. $B$, External Ba blocked the slowly activating outward $\mathrm{K}$ current at both stages (same stimulus protocol as in $A$ ). Bath, $10 \mathrm{~mm} \mathrm{Ba} / 0 \mathrm{CA}$ ASW. Relaxation of the current in $\mathrm{Ba}$ may reflect some time-dependent block of the lowthreshold component as well. $C$, Plot of $\tau$ versus voltage for voltagedependent $\mathrm{K}$ currents recorded as in $A$ for tailbud $(n=9)$ and tadpole ( $n=9$; mean \pm SEM). Activation of the single precursor cell $\mathrm{K}$ current was well fit at all voltages by a single exponential that reached an asymptotic value of $67 \mathrm{msec}$ at $+40 \mathrm{mV}$ (filled triangles). In mature muscle, activation of voltage-dependent $\mathrm{K}$ currents (in $0 \mathrm{Ca}$ ASW) was well fit by two exponentials at voltages positive to $0 \mathrm{mV}$. The higher threshold, slower component (filled circles) showed a $\tau$ versus voltage relation almost identical to that of the precursor cell $\mathrm{K}$ current, with an asymptotic value of $67 \mathrm{msec}$ at $+40 \mathrm{mV}$. The appearance of the higherthreshold slower component only at voltages positive to $0 \mathrm{mV}$ is consistent with this current being the same as the precursor cell $\mathrm{K}$ current, which activates only positive to $0 \mathrm{mV}$ (see. Fig. $4 D$ ). At voltages negative to $0 \mathrm{mV}$, currents in mature muscle are fit by a single, fast exponential, consistent with the presence of only the low-threshold component at these voltages (in $0 \mathrm{Ca}$ ASW).

cle the outward currents activated in Ca-free external solution were smaller and more slowly activating than those detected in Ca-containing solution (Fig. 4R). Isolation of the Ca-dependent component by subtraction (Fig. $4 C$, ASW minus $0 \mathrm{Ca}$ ASW) shows that it has both transient and steady-state components, and represents the fastest activating component of the total outward current. The Ca-dependent component comprised $54 \pm$ 
$13 \%(n=7)$ of the total outward current in mature muscle. Figure $4 D$ shows a plot of the current-voltage relation for the composite outward $\mathrm{K}$ currents, the outward currents remaining in $0 \mathrm{Ca} \mathrm{ASW}$, and the Ca-dependent currents (obtained by subtraction of these records) for both developmental stages. The results of these $0 \mathrm{Ca}$ experiments were confirmed in experiments where either $1 \mathrm{~mm}$ cadmium or $1 \mathrm{~mm}$ nickel was added to the external solution to block Ca entry (data not shown). Note that our observation that the $\mathrm{Ca}$-dependent $\mathrm{K}$ currents appear to activate at potentials well positive to the threshold for Ca current activation probably results from the inclusion of $\mathrm{Ca}$ currents in our subtraction procedure, which would tend to obscure small outward currents at negative potentials. A similar artifact could explain why the $\mathrm{Ca}$-dependent $\mathrm{K}$ currents do not decline in amplitude at very positive potentials, although this could also be due to an intrinsic voltage dependence of these channels (see Barrett et al., 1982).

The presence of $\mathrm{Ca}$-dependent $\mathrm{K}$ currents in mature muscle could reffect the appearance of these channels in the plasma membrane during development. Alternatively, as the amount of calcium entry increases during development, due to the increased amplitude and decreased inactivation of the Ca current, the amount of $\mathrm{Ca}$-dependent $\mathrm{K}$ current activated during voltage pulses could increase correspondingly even if the population of functional Ca-dependent $\mathrm{K}$ channels did not change. Finally the amplitude and time course of Ca-dependent $\mathrm{K}$ currents could be influenced by developmental changes in intracellular buffering, including the appearance of Ca-releasable $\mathrm{Ca}$ stores associated with the development of excitation-contraction coupling.

The voltage-dependent $\mathrm{K}$ current in the tailbud precursor cells appears to be retained in the mature muscle, although it is present at higher density. In addition, the mature muscle cells express a second, lower threshold voltage-dependent $\mathbf{K}$ current. Figure $5 \mathrm{~A}$ shows a comparison of the voltage-dependent $\mathrm{K}$ currents at the two stages. Records for the mature cell were obtained in $0 \mathrm{Ca}$, since this was necessary for isolation of mature muscle voltage-dependent currents. In the precursor cells, the outward current activates at about $+10 \mathrm{mV}$ and has an average activation $\tau$ of $67 \pm 16 \mathrm{msec}$ at $+40 \mathrm{mV}(n=9)$ in $0 \mathrm{Ca}$ (Fig. $5 \mathrm{C}$ ). In mature tadpole muscle, there are two components to the voltagedependent $\mathrm{K}$ current (Fig. 5A): a low-threshold rapidly activating current, activated at potentials positive to $-20 \mathrm{mV}$, and a slower component activated positive to $+10 \mathrm{mV}$. Analysis of activation kinetics in Ca-free solutions confirms the existence of two components of the voltage-dependent currents and also indicates that the high-threshold current has kinetics and voltage dependence very similar to the single $\mathrm{K}$ current in the tailbud precursor cells (Fig. $5 C$ ). At potentials negative to $+10 \mathrm{mV}$, currents are well fit by a single exponential with $\tau=46 \pm 17 \mathrm{msec}(n=6)$ at $-20 \mathrm{mV}$ and $\tau=17 \pm 10 \mathrm{msec}(n=9)$ at $0 \mathrm{mV}$. At more positive potentials, two exponentials are required: the faster $\tau$ fits on the $\tau$ versus voltage relation of the low-threshold component and saturates at values around $13 \mathrm{msec}$; the slower time constant saturates positive to $+40 \mathrm{mV}$ at values around $67 \mathrm{msec}$. The voltages at which the slower activating current appears are similar to those that activate the single $\mathrm{K}$ current in the tailbud precursor cells, and values of $\tau$ and the $\tau$ versus voltage relation are virtually identical for the two currents (Fig. 5C, solid symbols). Both the single delayed $\mathrm{K}$ current in tailbud cells and the high-threshold component of the voltage-dependent $\mathrm{K}$ current in mature were blocked by $10 \mathrm{~mm}$ external Ba (Fig. 5B). It appears therefore that the high-threshold slow $\mathrm{K}$ current in the mature muscle cells is the same as the single $\mathrm{K}$ current in the tailbud precursor cells, although it is present at about fivefold higher density in the mature muscle cells. The speeding of activation of the composite outward current during development is therefore caused, not by the acceleration of activation of the immature $\mathrm{K}$ current, but by the addition of more rapidly activating $\mathrm{Ca}$ and voltage-dependent $\mathrm{K}$ currents.

We cannot rule out the possibility that the low-threshold $\mathrm{K}$ current recorded in $0 \mathrm{Ca}$ ASW in mature muscle is residual $\mathrm{Ca}$ dependent $\mathrm{K}$ current activated, not by $\mathrm{Ca}$ influx, but by depolarization in the presence of ambient intracellular Ca levels.

\section{Reexpression of the inwardly rectifying potassium current in muscle}

An inwardly rectifying $\mathrm{K}$ current is present in all cells of the carly Boltenia embryo from before fertilization until gastrulation (densities ranging from 3.5-5.9 pA/pF; Block and Moody, 1987; Simoncini et al., 1988). This current disappears from all cells at late neurula/early tailbud stage, and is absent in the tailbud muscle precursor cells that we have studied (Fig. $6 \mathrm{~A}$, left). The inward rectifier is thus absent when the voltage-dependent inward $\mathrm{Ca}$ and outward $\mathrm{K}$ currents are first expressed in tailbud precursors. An inwardly rectifying current is present, however, in the mature muscle cells (Fig. 6A, right) and shows similar voltage dependence (Fig. 6B) and Ba sensitivity (Fig. 6C) to the earlier expressed current. The mean density of the current in mature tadpole cells at $-140 \mathrm{mV}$ is $\% \pm 3 \mathrm{pA} / \mathrm{pF}(n=19)$, similar to the density before its disappearance at the neurula stage. The inward rectificr is thus absent in the muscle lincage for only a window of developmental time between tailbud and the mature tadpole stages. We do not know if the inward rectifier also reappears in any nonmuscle cells in the tadpole.

\section{Action potentials in precursor cells and mature muscle}

We compared action potentials in tailbud precursor cells and mature muscle triggered during relatively long depolarizing current pulses $(250-500 \mathrm{msec})$ using perforated patch currentclamp recording. Although such measurements are more accurately made on spikes triggered after the termination of brief, high-amplitude pulses, we often found it difficult to trigger all or none spikes in this way from mature muscle cells, although not in precursor cells. This probably reflects the rapid activation of $\mathrm{K}$ currents in mature muscle.

As shown in Figure 7, cells at both stages were capable of generating overshooting action potentials. The peak amplitude of the spikes were not significantly different at the two stages. Action potentials in mature muscle, however, differed from those in tailbud precursor cells showing a faster rate of rise (tadpole, $10.2 \pm 4.06 \mathrm{mV} / \mathrm{msec}, n=6$, vs tailbud, $2.5 \pm 1.6 \mathrm{mV} / \mathrm{msec}$, $n=11$ ), a faster rate of fall (tadpole, $8.8 \pm 3.1 \mathrm{mV} / \mathrm{msec}, n=$ 6 , vs tailbud, $3.0 \pm 1.6 \mathrm{mV} / \mathrm{msec}, n=11$ ), and a shorter $\mathrm{du}-$ ration (tadpole $10.1 \perp 10.8 \mathrm{msec}, n=6$, vs tailbud, $31.6 \pm$ $6.8 \mathrm{msec}, n=11$ ). These differences are consistent with the developmental changes of $C$.a and $K$ currents seen under voltage clamp.

Although we found no differences in voltage or current threshold for spike generation between precursor cells and mature muscle, possibly because of large variability in these parameters among cells, we find that precursor cells were much more likely than mature cells to have depolarized resting potentials and to generate spontaneous action potentials. During a $10 \mathrm{sec}$ sample time near the beginning of current clamp recordings, all 
A.

Tailbud

B.

Figure 6. Inwardly rectifying $\mathrm{K}$ currents in mature muscle but not in tailbud precursor cells. $A$, Inwardly rectifying $\mathrm{K}$ current activated by $-10 \mathrm{mV}$ steps from $-70 \mathrm{mV}$ to $-160 \mathrm{mV}$ ( $V_{\text {hold }}$ $=-60 \mathrm{mV}$ ) in tadpole muscle (right) but not in tailbud precursor cells (left) Bath, ASW; pipette, $200 \mathrm{~mm} \mathrm{~K}$ internal solution. $B$, Current versus voltage relations for currents shown in $A$ and $C$. $C$, Block of the tadpole muscle inwardly rectifying $\mathrm{K}$ current by $10 \mathrm{~mm}$ barium (bath, $10 \mathrm{~mm} \mathrm{Ba} / 10 \mathrm{~mm} \mathrm{Ca}$ ASW).
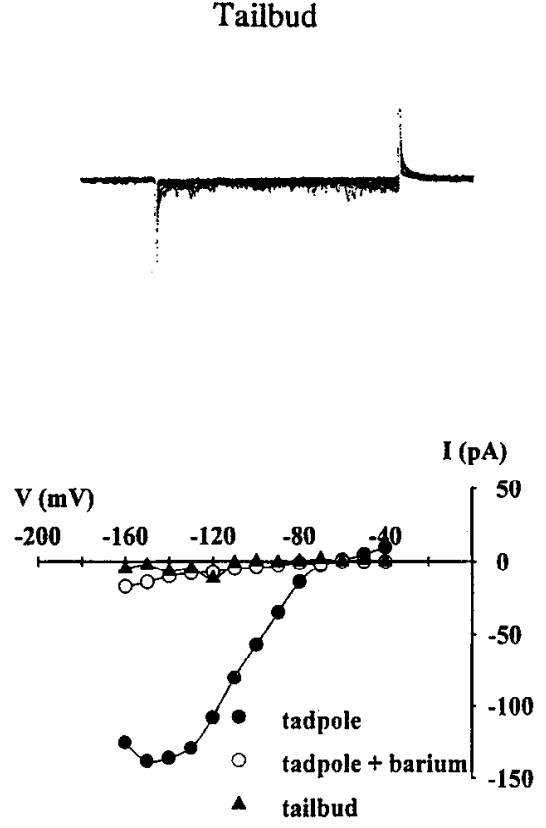

Tadpole

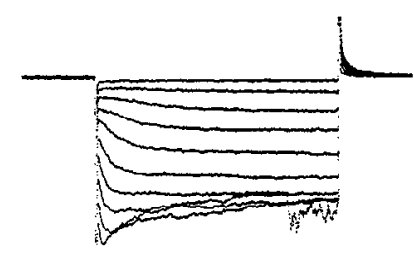

C.

$\mathrm{Ba}$

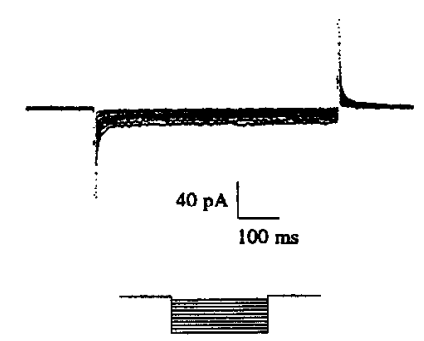

precursor cells ( $n=14$ ) showed resting potentials positive to $-30 \mathrm{mV}, 13$ out of 14 showed at least one spontaneous action potential and 9 out of 13 generated multiple spontaneous action potentials. In similar recordings from mature muscle, four out of five showed resting potentials negative to $-55 \mathrm{mV}$ and none generated even a single spontaneous action potential.

\section{Discussion}

We have demonstrated that both the amplitude and complexity of voltage-gated ionic currents increases with muscle differentiation in Boltenia larvae. These developmental changes are reflected in the current-clamp behavior of the cells. We have compared currents expressed in larval muscle from the tailbud stage
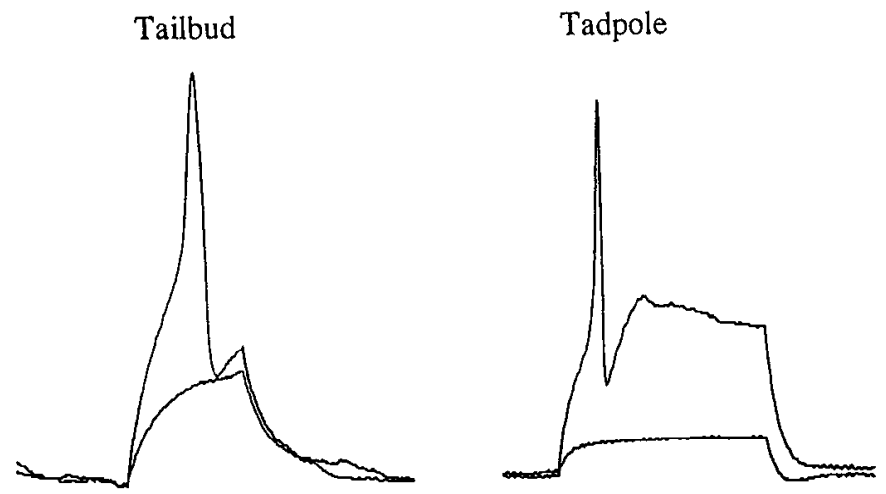

Figure 7. Longer duration action potentials triggered in immature tailbud precursor cells compared to mature muscle. A, Action potential stimulated by current injection ( $250 \mathrm{msec}$ duration, sub- and suprathreshold) in tailbud precursor muscle $\left(E_{m}=-64 \mathrm{mV}\right.$, with holding current). Bath, ASW; pipette, $200 \mathrm{~mm} \mathrm{~K}$ internal solution. $B$, Action potential stimulated by current injection $(500 \mathrm{msec}$ duration, sub- and suprathreshold) in tadpole muscle ( $E_{m}=-65 \mathrm{mV}$, no holding current). Bath, ASW; pipette, $200 \mathrm{~mm} \mathrm{~K}$ internal solution. Calibration: $21 \mathrm{mV}$, $230 \mathrm{msec}$.
(20-24 hr after fertilization) and the tadpole stage (7-11 hr later). Just before the tailbud stage the first lineage specific voltage-gated currents are expressed (Simoncini et al., 1988). In this study, we have observed that all immature muscle cells from tailbud-stage larvae express a transient, high-threshold $\mathrm{Ca}$ current and a slowly activating outward potassium current and many also express a very small, transient, low-threshold Ca current. At this stage, the inwardly rectifying $\mathrm{K}$ current, which had been present from the unfertilized egg until the late gastrula, is absent. Muscle cells from motile tadpole-stage larvae express two Ca currents (a transient, low-threshold and a sustained, highthreshold) and three outward potassium currents (a fast activating and a slowly activating voltage dependent and one $\mathrm{Ca}$ dependent) and reexpress an inwardly rectifying $\mathrm{K}$ current. The currents common to both developmental stages (the low-threshold transient $\mathrm{Ca}$ current and the high-threshold voltage-dependent $\mathrm{K}$ current) are present at higher densities in mature cells.

A notable finding in our study is that although Boltenia muscle follows the pattern of increasing density and activation rate of outward $\mathrm{K}$ currents during development seen in other cell types (see, e.g., Barish, 1986 and O'Dowd et al., 1988), it achieves the increased activation rate by a somewhat different mechanism. In Xenopus neurons, for example, the delayed $\mathrm{K}$ current present just after the neurula stage shows about a twofold increase in activation rate over the next 1-3 d. Although a rapidly activating $\mathrm{A}$-current and a transient $\mathrm{Ca}$-dependent $\mathrm{K}$ current also appear during this time, modeling studies indicate that the increase in density of the delayed $\mathrm{K}$ current is the main determinant of acceleration of the composite $\mathrm{K}$ currents and the shortening of the action potential (Lockery and Spitzer, 1992). In Boltenia muscle, the delayed $\mathrm{K}$ current present in the immature precursor cells just after neurulation does not speed its rate of activation. However, the two other outward currents that appear during development, the Ca-dependent $\mathrm{K}$ current and the lowthreshold voltage-dependent $K$ current activate much faster than the mature form of the delayed $\mathrm{K}$ current (average time constant measured at $+40 \mathrm{mV}$; Ca dependent, $9 \mathrm{msec}$; low-threshold $\mathrm{K}$, $13.5 \mathrm{msec}$; mature delayed K, $69 \mathrm{msec}$ ). Since these two currents 
contribute nearly $75 \%$ of the total outward current at $+40 \mathrm{mV}$, it is their appearance, rather than the developmental modification of the precursor cell delayed $\mathrm{K}$ current that most likely determines action potential waveform in mature cells.

A second important finding is that the inwardly rectifying $\mathrm{K}$ current is absent for only a relatively short window of time during muscle development. Our previous experiments on early Boltenia embryos showed that the inwardly rectifying $\mathrm{K}$ current is present in the unfertilized oocyte and is maintained at constant density (which requires continuous upregulation because of increasing surface area) in all cells of the embryo until the neurula stage (Block and Moody, 1987; Simoncini et al., 1988). Near the time of neurulation, the inward rectifier is eliminated in all cells of the embryo. The present experiments show that this current reappears in the mature muscle cells, demonstrating that its absence in the muscle lineage is restricted to a period of developmental time beginning at the neurula stage and ending at most $7 \mathrm{hr}$ later. During at least the first part of this window of time, a $\mathrm{Ca}$ current is present in the precursor cells, but the only $\mathrm{K}$ current expressed is the high-threshold delayed $\mathrm{K}$ current, which, at this stage, is small and activates slowly. This combination of voltage-gated currents sets up an electrophysiological situation favoring spontaneous activity and calcium entry: low resting membrane conductance caused by the transient absence of the inward rectifier, which represents most, if not all, of the resting conductance in these cells, and slow activation kinetics of the outward $\mathrm{K}$ currents. In addition, if $\mathrm{Ca}$ current density increases and inactivation decreases before the inward rectifier reappears, action potential generation will be even more likely in the later stages of this window. Indeed, in current-clamp recordings, spontaneous action potentials were seen in a majority of precursor cells, but in none of the mature muscle cells. However, such data must be interpreted with caution because the absence of the inward rectifier, which we propose to be partially responsible for spontaneous activity, would also make the precursor cells more sensitive to depolarization caused by current leak across the recording electrode seal resistance.

The sequence of expression of Ca currents in differentiating Boltenia muscle partially agree with those obtained in differentiating mammalian skeletal myotubes (newborn), where T-type currents are more prominent early and L-type currents are more prominent 3 weeks later (Beam and Knudson, 1988; Gonoi and Hasegawa, 1988). We record very small T-type currents soon after the first lineage-specific currents are expressed, though a transient, high-threshold, dihydropyridine sensitive current is more prominent at early times. This high-threshold, dihydropyridine sensitive current differs from the high-threshold current expressed in mature tadpole-stage muscle in inactivation properties: the immature current shows Ca-dependent inactivation while the mature muscle current is more like a typical L-type Ca current showing little inactivation. Therefore, in Boltenia muscle, like mammalian muscle, L-type Ca currents are expressed at later developmental stages than T-type Ca currents. In mammals, the study of calcium current cxpression during muscle development begins after muscle is morphologically identifiable. Our observation that immature muscle expresses an inactivating, high-threshold $\mathrm{Ca}$ current before expressing a T-type current may be the result of our ability to examine muscle precursors at very early stages of differentiation. A similar pattern of $\mathrm{Ca}$ current expression in developing mammalian muscle has not yet been detected, but there are indications that study of muscle at earlier developmental stages might reveal transient expression of different voltage-gated Ca currents. For example, developing mouse muscle expresses mRNA for the cardiac isoform of the dihydropyridine calcium channel prior to expression of the skeletal muscle isoform (Chaudhari and Beam, 1993) though functional expression of a corresponding cardiac-like $\mathrm{Ca}$ current in immature muscle has not been reported.

Between the two stages we have compared, the muscle cells become contractile in response to direct depolarizing stimuli. The relative contributions of $\mathrm{Ca}$ entry and internal $\mathrm{Ca}$ release to contraction of the larval ascidian muscle are not clear, although ultrastructural evidence suggests that ascidian muscle may resemble vertebrate cardiac, rather than skeletal muscle (Cavey and Cloney, 1972). This would be consistent with an action potential dependent exclusively on $\mathrm{Ca}$, rather that $\mathrm{Na}$, entry. It is likely therefore that the developmental changes in Ca current amplitude and waveform we have observed have effects on contractility. It will be interesting to compare the exact time course of these changes to the development of innervation and excitation-contraction coupling.

Our results show some similarities to and some differences from results obtained in cleavage-arrested muscle-lineage blastomeres from another ascidian, Halocynthia roretzi (Takahashi and Yoshi, 1981; Hirano et al., 1984; Okado and Takahashi, 1990; Shidara and Okamura, 1991). Mature Halocynthia muscle showed only a single, high-threshold, transient $\mathrm{Ca}$ current, which resembles the $\mathrm{Ca}$ current we record from immature tailbud precursor cells in both voltage-dependence and inactivation mechanism. In developing Halocynthia muscle, two types of voltagedependent outward $\mathbf{K}$ currents were expressed that had similar activation kinetics but were distinguishable by their different sensitivities to TEA. The TEA-sensitive current activated at more positive voltages than the TEA-insensitive current, and increased in its rate of activation about twofold during development. Although we did not test TEA sensitivity, these results are similar to ours in that mature muscle cells show two voltagedependent outward $\mathrm{K}$ currents, but our results differ in that our high-threshold $\mathrm{K}$ current does not increase its activation rate during development and it is much slower in activation than the low-threshold current. In both species, a Ca-dependent outward $\mathrm{K}$ current and an inwardly rectifying $\mathrm{K}$ current developed in mature muscle. The developmental time course of the inwardly rectifying $\mathrm{K}$ current in Halocynthia appeared to depend somewhat on the experimental conditions. In cleavage-arrested 16cell embryos, the inward rectifier increased throughout development and showed no minimum or period of absence as we have seen (Takahashi and Yoshi, 1981). These results, however, might be affected by differences between individual blastomeres and by patterns of electrical coupling, because intact embryos, rather than individual cells were voltage clamped in these experiments. In cleavage-arrested one-cell embryos, however, the inward rectifier showed a minimum, although not a complete absence, at stages similar to those when it is absent in our experiments (Hirano and Takahashi, 1987). We do not know whether the differences between our results and those in Halocynthia are due to species differences or to the use of early blastomeres that develop in the absence of cell divisions in the Halocynthia experiments.

Our results support the hypothesis that functional channel properties in excitable cells do not necessarily develop monotonically, but rather proceed through discrete stages during which the properties of the cells are qualitatively different from those found in the mature state. The coordinated developmental 
modulation of several voltage- and Ca-dependent channel types defines one such period in Boltenia muscle just after neurulation. The period begins with the elimination of the inward rectifier, the major resting conductance of these cells, and ends at some time less than $7 \mathrm{hr}$ later with its reappearance and the development of rapidly activating $\mathrm{Ca}$ - and voltage-dependent $\mathrm{K}$ currents. The exact timing of the end of this window of development, the contribution of the various channel types to initiating and terminating possible spontaneous activity during this time, and the developmental significance of such activity are currently under study.

\section{References}

Adams BA, Beam KG (1991) Contractions of dysgenic skeletal muscle triggered by a potentiated, endogenous calcium current. J Gen Physiol 97:687-696.

Barish ME (1986) Differentiation of voltage-gated potassium current and modulation of excitability in cultured amphibian neurones. $J$ Physiol (Lond) 375:229-250.

Barish ME (1991) Increases in intracellular calcium concentration during depolarization of cultured Xenopus spinal neurones. $J$ Physiol (Lond) 444:545-565.

Barrett JN, Magleby KL, Pallotta BS (1982) Properties of single calcium-activated potassium channels in cultured rat muscle. J Physiol (Lond) 331:211-230.

Beam KG, Knudson CM (1988a) Calcium currents in embryonic and neonatal skeletal muscle. J Gen Physiol (Lond) 91:781-798.

Beam KG, Knudson CM (1988b) Effect of postnatal development on calcium currents and slow charge movement in mammalian skeletal muscle. J Gen Physiol 91:799-815.

Block ML, Moody WJ (1987) Changes in sodium, calcium and potassium currents during early embryonic development of the ascidian Boltenia villosa. J Physiol (Lond) 393:619-634.

Broadie KS, Bate M (1993) Development of larval muscle properties in the embryonic myotubes of Drosophila melanogaster. $\mathbf{J}$ Neurosci 13:167-180.

Caffrey JM, Brown AM, Schneider MD (1989) $\mathrm{Ca}^{+}$and $\mathrm{Na}^{+}$currents in developing skeletal myoblasts are expressed in a sequential program: reversible suppression by transforming growth factor beta-1, an inhibitor of the myogenic pathway. J Neurosci 9:3442-3453.

Cavey MI, Cloney RA (1976) Ultrastructure and differentiation of ascidian muscle. Cell Tissue Res 174:289-313.

Chaudhari N, Beam KG (1993) mRNA for cardiac calcium channel is expressed during development of skcletal muscle. Dcv Biol 155:507515.

Cognard C, Constantin B, Rivet-Bastide M, Imbert N, Besse C, Raymond G (1993) Appearance and evolution of calcium currents and contraction during the early post-fusional stages of rat skeletal muscle cells developing in primary culture. Development 117:1153-1161.

Cota G, Stefani E (1984) Saturation of calcium channels and surface charge effects in skeletal muscle fibres of the frog. J Physiol (Lond) 351:135-154

Desarmenien MG, Spitzer NC (1991) Role of calcium and protein kinase $\mathrm{C}$ in development of the delayed rectifier potassium current in Xenopus spinal neurons. Neuron 7:797-805.

Fox AP, Nowycky MC, Tsien RW (1987) Kinetic and pharmacological properties distinguishing three types of calcium currents in chick sensory neurones. J Physiol (Lond) 394:149-172.

Gonoi T, Hasegawa S (1988) Post-natal disappearance of transient calcium channels in mouse skeletal muscle: effects of denervation and culture. J Physiol (Lond) 401:617-637.

Gonoi T, Hasegawa S (1991) Postnatal induction and neural regulation of inward rectifiers in mouse skeletal muscle. Pfluegers Arch 418 601-607.
Hamill OP, Marty A, Neher E, Sakmann B, Sigworth F (1981) Improved patch clamp techniques for high-resolution recording from cells and cell-free membrane patches. Pfluegers Arch 391:85-100.

Hess P (1990) Calcium channels in vertebrate cells. Annu Rev Neurosci 13:337-356.

Hirano T, Takahashi K (1987) Development of ionic channels and cellsurface antigens in the cleavage-arrested one-cell embryo of an ascidian. I Physiol (Lond) 386:113-133.

Hirano T, Takahashi K, Yamashita N (1984) Determination of excitability types in blastomeres of the cleavage-arrested but differentiated embryos of an ascidian. J Physiol (Lond) 347:301 325

Holliday J, Spitzer NC (1990) Spontaneous calcium influx and its role in differentiation of spinal neurons in culture. Dev Biol 141:13-23.

Horn R, Marty A (1988) Muscarinic aclivation of ionic currents measured by a new whole-cell recording method. J Gen Physiol 92:145159.

Hussy N (1991) Developmental change in calcium-activated chloride current during the differentiation of Xenopus spinal neurons in culture. Dev Biol 147:225-238.

Jones SM, Ribera AB (1994) Overexpression of a potassium channel gene perturbs neural differentiation. J Neurosci 14:2789-2799.

McCobb DP, Best PM, Beam KG (1989) Development alters the expression of calcium currents in chick limb motoneurons. Neuron $2: 1633-1643$

Narahashi T, Tsunoo A, Yoshii M (1987) Characterization of two types of calcium channels in mouse neuroblastoma cells. J Physiol (Lond) 383:231-239.

O'Dowd DL, Ribera AB, Spitzer N (1988) Development of voltagedependent calcium, sodium, and potassium currents in Xenopus spinal neurons. J Neurosci 8:792-805.

Ohmori $H$ (1978) Inactivation kinetics and steady-state current noise in the anomalous rectifier of tunicate egg cell membranes. J Physiol (Lond) 281:77-99.

Ohmori H, Sasaki S (1977) Development of neuromuscular transmission in a larval tunicate. J Physiol (Lond) 269:221-254.

Okado H, Takahashi K (1990) Differentiation of membrane excitability in isolated cleavage arrested blastomeres from early ascidian embryos. J Physiol (Lond) 427:583-602.

Ribera AB, Spitzer NC. (1991) Differentiation of delayed rectifier potassium current in embryonic amphibian myocytes. Dev Biol 144: $119-128$.

Ribera AB, Spitzer NC (1992) Developmental regulation of potassium channels and the impact on neuronal differentiation. In: Ion channels, Vol 3 (Narahashi, T, ed). New York: Plenum.

Salkoff $L$ (1985) Development of ion channels in the flight muscle of Drosophila. J Physiol (Paris) 80:275-282.

Satoh N, Deno T, Nishida H, Nishikata T, Makabe K (1990) Cellular and molecular mechanisms of muscle cell differentiation in ascidian embryos. Int Rev Cytol 122:221-258

Shidara M, Okamura Y (1991) Developmental changes in delayed rectifier $\mathrm{K}$ currents in the muscular- and neural-type blastomere of ascidian muscle. J Physiol (Lond) 443:277-305.

Simoncini L, Block ML, Moody WJ (1988) Lineage-specific development of calcium currents during embryogenesis. Science 242: $1572-1585$.

Sontheimer H, Trotter J, Schachner M, Kettenman H (1989) Channel expression correlates with differentiation stage during development of oligodendrocytes from their precursor cells in culture. Neuron 2:1135 1145 .

Spitzer N (1991) A developmental handshake: neuronal control of ionic currents and their control of neuronal differentiation. J Neurobiol 22:659-673.

Spruce AE, Moody WJ (1992) Developmental sequence of expression of voltage-dependent currents in embryonic myocytes. Dev Biol 154: $11-22$.

Takahashi K, Yoshii M (1981) Development of sodium, calcium and potassium in the cleavage-arrested embryo of an ascidian. $\mathrm{J}$ Physiol (Lond) 315:515-529. 